\title{
Leadership and the role of women in the success of logistics companies
}

\author{
Katarzyna Kolasińska-Morawska, Łukasz Sułkowski, Marta Brzozowska
}

\section{A B S T R A C T}

Objective: The objective of this article is discussing the role and importance of women's leadership qualities in shaping the business success of firms in the logistics industry.

Research Design \& Methods: Research was divided into two steps. Data was collected from both primary and secondary sources. Authors used monographic methods, along with an evaluation of documents in terms of their publication usefulness. In the next step, data was collected from primary sources: women working in the logistics industry as managers or managing their own firms - the technique applied was based on individual in-depth interviews, as well as employees of logistics companies led by women - the technique applied was direct questionnaires.

Findings: As the conducted research shows, the growing authority of women in the logistics industry results from their having the fundamental qualities and competences that should characterize an effective leader. In addition, some personality traits characteristic of women proves to be extremely useful in the multi-stimuli corporate environment. Therefore, women are perfectly capable of managing logistics.

Contribution \& Value Added: According to the authors' recommendations, the study should be expanded to include a larger group of respondents. Moreover, there should be included companies from different parts of the world. In addition, the next step should consider the socio-cultural conditions of the firm's country of origin.

\begin{tabular}{ll}
\hline Article type: & research paper \\
Keywords: & Leadership; success in business; logistics; empower; womanager \\
JEL codes: & F23, L2O
\end{tabular}

Article received: 10 October 2019

Article accepted: 16 December 2019

\section{Suggested citation:}

Kolasińska-Morawska, K., Sułkowski, Ł., \& Brzozowska, M. (2019). Leadership and the role of women in the success of logistics companies. International Entrepreneurship Review (previously published as International Entrepreneurship / Przedsiębiorczość Międzynarodowa), 5(4), 93-107. https://doi.org/10.15678/IER.2019.0504.06

\section{INTRODUCTION}

As trends in social and economic environment that form the outside of an organization inertly influence its inside, interactiveness and interdependence between a firm and its 
environment become particularly strong. Currently, globalization, internationalization, technologization, computerization and customization result in a decision-making individual being confronted with new challenges. The world has shrunk. The pressure to work faster is a phenomenon that has arisen the demand for information and knowledge is almost limitless. As a result, intellectual capital becomes the most valuable resource, which is often strongly correlated with a firm's market success. Thus, reputation, guidance and leadership gain a new aspect, especially in terms of the structure of the members who cocreate and manage organizations.

This article is aimed at discussing the role and importance of women's leadership qualities in shaping the business success of firms in the logistics industry.

To achieve the said aim, the authors had to specify areas of consideration. In accordance with the adopted research procedure, the following questions were put forward: What is leadership as understood in literature on the subject? Can success be defined unambiguously? Is there any relationship between leadership and the business success of firms? What is the role of women in the modern economy? How important are such factors as personality, the system of values, cultural patterns and education on a women's path to become a success-oriented leader? What is the current position of female leaders in the logistics industry?

\section{MATERIAL AND METHODS}

To reach their set goal, the authors of this article had to find answers to the above questions. Thus, the authors had to apply a multi-component research methodology that involved a specific type of reasoning, based on analysis, synthesis and inference arising from deduction in accordance with the laws of logic. They started their research by collecting information both from secondary sources, including available printed and digital sources, and from primary sources: women working in the logistics industry as managers or managing their own firms, as well as employees of logistics companies led by women. In the research analysis of secondary sources, monographic methods were applied, along with an evaluation of documents in terms of their publication usefulness. The content of the selected publications was analysed using the technique of semantic analysis of the co-occurrence of terms. The material obtained from secondary sources was supplemented with that from primary sources. In cases of women working in the logistics industry as managers or managing their own firms, the technique applied was based on individual in-depth interviews, and in cases of employees of logistics companies led by women, direct questionnaires were used.

\section{LITERATURE REVIEW AND THEORY DEVELOPMENT}

The modern economic and social development of countries and individual business entities depends on many different factors. One of them is leadership. Its importance is because the changing environment promotes those who are characterized by their creativity, flexibility, willingness to face new challenges, optimism, focus on constant self-improvement and an ability to gather around themselves other people eager to pursue their visions. In every organization, the presence of successful leaders exerts a significant influence on its effectiveness and efficiency. Leaders motivate, support and inspire. 
Historical theories of leadership place emphasis on its various aspects. According to trait theories, some people are born leaders, which can be determined by quantification of their personality traits and attributes (social, physical and intellectual ones). Behavioural theories, on the other hand, referred to quantification of behavioural patterns, with the basic assumption that people can be taught specific behaviours, and thus possibly trained to become leaders. Finally, there is a group of situational theories which suggest that leadership behaviours are situation-dependent, i.e. it is possible to identify a group of situational factors that favour such behaviours (Griffin, 2004).

Modern theories, in addition to historical views, also consider an additional aspect that characterizes leadership: "leaders inspire others with their words, concepts and behaviours" (Robbins, 2012). These are transformational and charismatic leadership theories. Transformational leadership theory refers to the motivational aspect, with emphasis on the importance of inspiration, creativity and innovativeness - qualities that leaders should possess to make their subordinates believe that the goals of the organization are important to them personally. Charismatic leadership theory, on the other hand, refers to charisma, or to a group of such personality traits such as optimism, enthusiasm, communicativeness, relationality, unconventionality, courage and sensitivity to the needs of other people, which allow a leader to influence others. Also, strategies engaged in the construction of leadership in three different yet apparently interrelated domains of public life and public policy, political communication, management/business discourse, and academic communication are considered as very important (Lehman, Sułkowski \& Cap, 2019). Another perspective of women's leadership is gender diversity. Authors explore this subject in academia context. Starting from thesis that there is large disproportion in the number of highest power positions in between men and women in academia they came to conclusion that such model is more related to public universities but not private universities where both men and women are treated equally (Sułkowski, Bogacz-Wojtanowska \& Wrona, 2019). Also, other authors confirm that institutions of higher education are in nations with their own specific historical, cultural, social, economic, legal and political legacies that render comparisons difficult (Fitzgerald, 2014). When examining, analysing and evaluating female and male leaders, gender operates as first series of prisms (Klenke, 2004). In that context the nation can ill afford to exclude so many talented women from positions of influence, particularly given the growing body of evidence suggesting that women bring distinctive strengths to these roles (Rhode, 2017; Waters-Sobkowiak, Kowalski \& Smits, 2018). Moreover, authors in (Stober-Walker \& Haber-Curran, 2017) express that equality for women and girls is sorely needed in today's world and they believe that theorizing in this domain has the power to positively impact the future. But still there is a lot of resistance to women's leadership. In the language of psychologists, the clash is between two set of associations: communal and agentic. Women are associated with communal qualities, which convey a concern for the compassionate treatment of others while agentic traits are associated in most people's minds with effective leadership perhaps because of long history of male domination of leadership roles (Ibarra \& Tannen, 2018). Also, socially people are getting increasingly accustomed to seeing women in management and leadership positions. However, because of many men and women's early social conditioning, some simply cannot get used to the idea of woman as a credible leader in the workplace (Rezvani, 2009). Ultimately, women who seek top management positions must weed 
through culturally formed stereotypes and at the same time avoid crossing culturally generated barriers (Belasen, 2012). According to Fabiańska (2016) the next generation of women is characterised by great openness to changes and willingness to take risks.

Perhaps solution is an emotional agility? Emotional agility is a four-step approach that allows women to navigate life's twists and turns with self-acceptance, clear-sightedness, and an open mind. No matter how intelligent, resilient, or creative people are, when they ignore how situations or interactions make them feel, they miss opportunities to gain insight, getting hooked by thoughts, emotions, and habits that prevent them from reaching their full potential (David, 2016). Also, success in business is very important factor. Success means making meaningful work that promotes inclusivity and community (Bonney, 2016). The strategies for success that fallow is about doing things differently. The status quo has been left alone for too long now and it is time for change. There is fundamental shift in the way most businesses work. It is time that businesses looked after their talented women employees to ensure that they reap the returns that this will deliver in terms of loyalty, experience and success (Unerman \& Jackob, 2016). Finally, the shortfall of women willing and can enter political leadership presents a double bind for increasing the numbers (O'Connor, 2010).

Thus, leadership is the art of leading people where they would not be able to go on their own (Owen, 2003). Leadership is an ability to influence a group to pursue a vision or a set of goals (Robbins, 2012). Leadership involves encouraging and inspiring people and teams to do their best to reach the desired result (Armstrong, 1997). Leadership can be perceived as an ability to engage others in the process of reaching a goal as part of a larger system or environment. In addition, the nature of leadership is never uniform (Kędziora, Piotrowicz \& Kolasińska-Morawska, 2018). We can identify formal, granted leadership and non-formal leadership, leadership that is people-oriented and the one that is task-oriented, traditional leadership of a legal and rational character, and charismatic leadership based on extraordinariness and exceptionality. In addition, we can distinguish between autocratic and democratic-liberal leadership and overt and covert leadership.

From the etymological perspective, 'success' means both a venture and its positive result. Some related terms are positive result, favourable outcome, prosperousness, prosperity, achievement, accomplishment, feat, coup, victory, win and triumph (KolasińskaMorawska, 2014). It is difficult to propose a single definition of success that would encompass all its aspects, as - to paraphrase W. Clement Stone - "the core of one's success is his or her underlying philosophy." In other words, there are as many definitions of success as there are those who try to define it. Each man or woman who undertakes various tasks sets some goals for himself or herself - specific points in time and space that they want to achieve. These achievements are then marked out as successes or failures.

A successful individual is a person who feels happy and fulfilled. Indeed, a well-balanced individual can achieve success in every field and derive satisfaction from it. By way of analogy, that definition of success can be also applied to a company, where fixed assets represent the body, relationships - both intra-corporate and those between the company and its environment - represent emotions, employees' knowledge and corporate knowhow represent the intellect, and corporate values represent the spirit. People of success are admired. Many would like to trade places with them. The force that makes them pursue their success is largely connected with motivation. Highly motivated people can push 
limits and go beyond themselves to accomplish much more than they had planned (Nkwocha, 2013). In this context, motivation is of crucial importance as a process occurring in human consciousness and resulting in a desire to do something, i.e. a motive. However, for such a motive to be shaped, specific conditions must be met. First, there must be a need, a feeling that something is missing. Second, the need must be important. Third, an individual must see an opportunity to satisfy that need. The need associated with the craving for success refers to overcoming obstacles when performing difficult tasks, with maximum use of one's own assets in a specific field. In addition to an analysis from the angle of negative pressure, subject literature also discusses the need for success in the context of achievements (McClelland, 1961). It arises from people's manifestations of values that have been instilled in them their whole lives. In such a case, motivation is additionally strengthened by rising to challenges that allow an individual to push his or her limits. High self-esteem is also an important factor. In addition, it should be remembered that the motivation to reach set goals can be shaped by an appropriate educational system. Thus, we are not born people of success. We become them.

As the general women's activation trend shows, increasingly more women undertake studies, which makes them better educated than men (Figure 1). As per the Eurostat report, in 2016, the estimated total percentage of female students in EU-28 countries was $54.1 \%$. The percentage of women was a little higher in cases of master's students $(57.1 \%)$ and a little lower in cases of bachelor's students $(53.2 \%)$ and participants of short-cycle programmes (52.1\%).

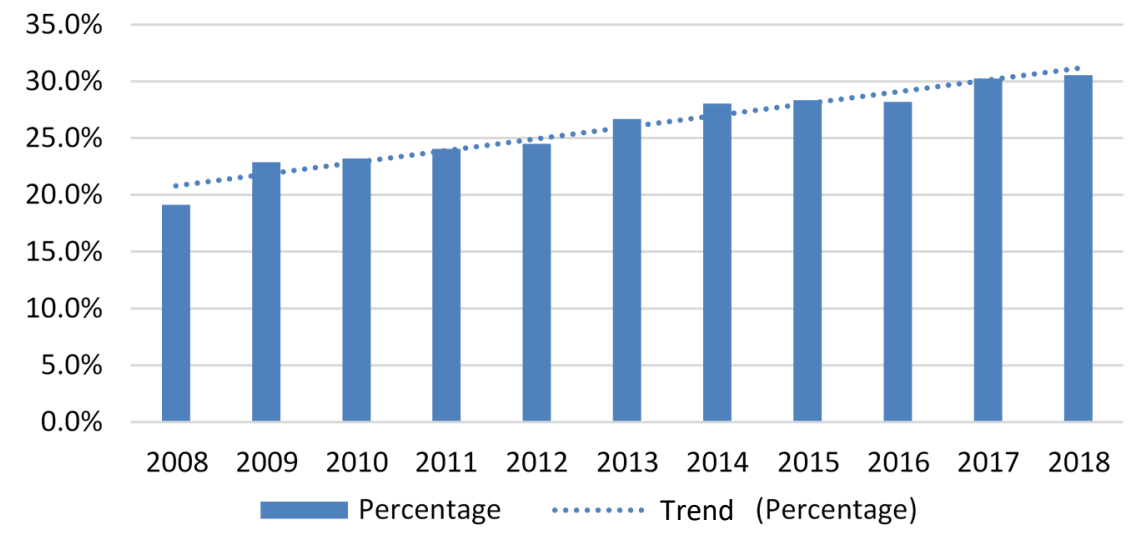

Figure 1. Dynamics of growth in the number of women studying logistics at the University of Social Sciences in the period 2008-2018 Source: data from the POL-on system per October 31.

In Poland, an increasing number of women take up studies in various fields, including logistics. One case in point is the University of Social Sciences in Łódź where the percentage of female logistics students is growing by the year (when analysing the data from the recent decade, the increase amounts to slightly over $10.0 \%$ in the period from 2008 to 2018). Women complete studies to improve their qualifications, which makes it easier for them to find employment in logistics. Now, meeting a female semi-trailer truck, bus or railway engine driver, forklift truck operator, storekeeper or quality controller is no longer 
as surprising as it used to be. Women feel perfectly comfortable in the so-far male-dominated world of logistics. They have appropriate knowledge and skills, and when this is not enough to do the job, their sensitivity and empathy prove invaluable.

Leadership qualities differ from managing competences and are particularly highly valued in logistics where teamwork is the dominant model. Literature about this provides many examples of research into leadership qualities. Rossiter names such qualities as innovativeness, respect for others, politeness and sensitivity (Rossiter, 2014). She also points out the fact that leaders function well in a team, demonstrating creativity and willingness to communicate with other team members, which makes them trustworthy, and they are also well-organized. One leadership quality that is much discussed today is empowerment. Sashkin (2018) proposes a scale to measure leadership qualities. The researcher identifies the following leadership indicators: skilful management; recognizing the potential; leadership communication; reliable, caring, trusted, follower-focused, visionary, culture-building leadership.

In the case of logistics, leadership qualities can result from the specific character of this industry. Subject literature divides logistics management skills into several categories (Gibson, Gibson \& Rutner, 1998). Emphasis is put on orientation towards people in the context of leadership, but also with reference to teamwork or conflict management. However, it should be noted that research by Murphy and Poist (2007) suggests that managing competences are still considered the most important, while knowledge and logistics experience come second.

\section{RESULTS AND DISCUSSION}

Primary material was collected from two research samples: female managers or owners of logistics firms and employees of such firms. In cases of women working in the logistics industry as managers or managing their own firms, the technique applied was based on individual in-depth interviews, and in the case of employees of logistics companies led (i.e. owned or managed) by women, direct questionnaires were used. The first research sample consisted of 20 women selected with the use of a non-random typical case snowball sampling method, applying the criterion of at least 2 years of experience as a logistics manager. The second research sample consisted of 924 employees selected with the use of a quota sampling method, applying the criteria of at least 2 years of experience as an employee in a logistics company and functioning within the structures of a firm owned or managed by a woman being the respondent's superior. We should start by presenting main issues raised by the female owners or managers of logistics firms participating in the research.

After the research, the original data obtained from the interview was counted and analyzed for existing common threads in the statements of the study participants. In turn, the material obtained from a direct survey of employees of logistics companies was subjected to formal and substantive verification. Then, the collected material, after coding the data in accordance with the adopted coding system, was transferred to aggregate information sheets using the Microsoft Excel and SPSS tool (Statistical Package for the Social Sciences) programs to process and analyze the data. Firstly, the distribution was analyzed using descriptive statistics methods. In the second step, where there was justification, an attempt was made to determine the possibility of relationships between selected variables, using cross-combinations and determining the boundary 
values. The basis for examining the relationship between features was the table of independence (contingencies), which was used to order at least two features at the same time. This table consisted of $r$ rows and s columns, with each row (column) corresponding to variants of the $X(Y)$ feature. The interior of the contingency table consists of the numbers $n_{i j}$ of those elements of the sample that have the $i$-th variant of the feature $X$ $(i=1,2, \ldots ., r)$ and the $j$-th variant of the feature $Y(j=1,2, \ldots, s)$. Contingency tables allowed to verify partial hypotheses about the existence of stochastic independence between $X$ and $Y$ variables. $X^{2}$ statistics were used to verify the $H_{0}$ hypothesis about stochastic independence of variables. They use the methodology for testing hypotheses about the statistical significance of the relationship between variables using the SPSS computer program, the value of statistics and significance levels for selected pairs of variables were determined. The verification of the statistical significance of the observed dependencies of individual variables consisted in checking whether for the value of the chi-square statistics of a given pair of analyzed variables, the value of the parameter of asymptotic significance is less than 0.05 . If so, the observed relationship between variables could be considered statistically significant. The results obtained from the analysis of empirical material were the basis for verifying the truth of the hypotheses of the study on the existence of possible relationships.

\section{Female owners and managers of logistics companies about female leaders}

Most of the research participants declare that they have been working as managers for 5 to 10 years $(50.0 \%)$ or more than 10 years. They represent medium-sized firms employing 50 to 250 people (40\%) or more than 250 people (40\%). They also declare that currently, they manage teams of 50 people (30\%), 50 to 250 people (40\%) or more than 250 people (30\%). Most of them are aged $31-45$ years $(60 \%)$ or over 45 years $(30 \%)$. In terms of their education, they hold academic degrees, usually MSc or MBA (60\%).

As regards the sex of a leader, our female respondents claimed that it is completely irrelevant to them. What is important is the person's knowledge, skills and attitude to his or her colleagues. A potential head of a company should demonstrate not only pragmatic knowledge in the firm's area of activity, but also have a good understanding of economics and psychology. He or she should be resolute, as well as patient and capable of staying calm. A leader should be able to listen, encourage dialogue and have experience in conflict resolution.

In reference to the issue of a leader's sex, the female respondents pointed out that women, in order to be appreciated as managers, should be professional in everything they do and come up with original ideas. According to the respondents, women "should avoid revealing excessive emotions at work, including bringing events or emotions from their personal lives into the professional sphere." Companies that enjoy success under 'womanagement' owe it to the determination, professionalism, commitment, empathy, creativity and diligence of their female leaders. According to the research participants, "women analyse, organize and plan more easily and quickly, they think longterm and specify the conditions realistically, instead of fooling themselves. Therefore, they are more effective than men." They are characterized by their non-standard approach to solving problems. 


\section{Employees of logistics companies about female leaders}

Having analysed the results of research with the participation of female owners or managers of logistics companies, we should now consider the opinions of employees functioning within the structures of such companies.

In this research sample, the dominant group are women (69.9\%), while men are in the minority (30.1\%). Over a half of the respondents (56.5\%) are aged $31-45$ years, and one in three is a representative of the under-30 age group (29.1\%). According to the declarations, almost half of the research participants have secondary education (44.9\%), one in three holds a bachelor's degree (35.7\%), and one in seven completed master's or doctoral studies (15.9\%). Most of the participants declare that they work within the structures of companies employing more than 50 people $(41.3 \%)$ or more than 250 people (39.0\%). Over a half of the respondents are line or middle-ranking employees (57.0\%). The sample is dominated by people from Poland $(42.6 \%)$ and the UK (28.4\%). Other research participants come from Germany (6\%), Spain (5.8\%), Italy (4.9\%), Croatia (4.1\%), Greece (3.0\%), France (2.6\%) and the Czech Republic (1.8\%).

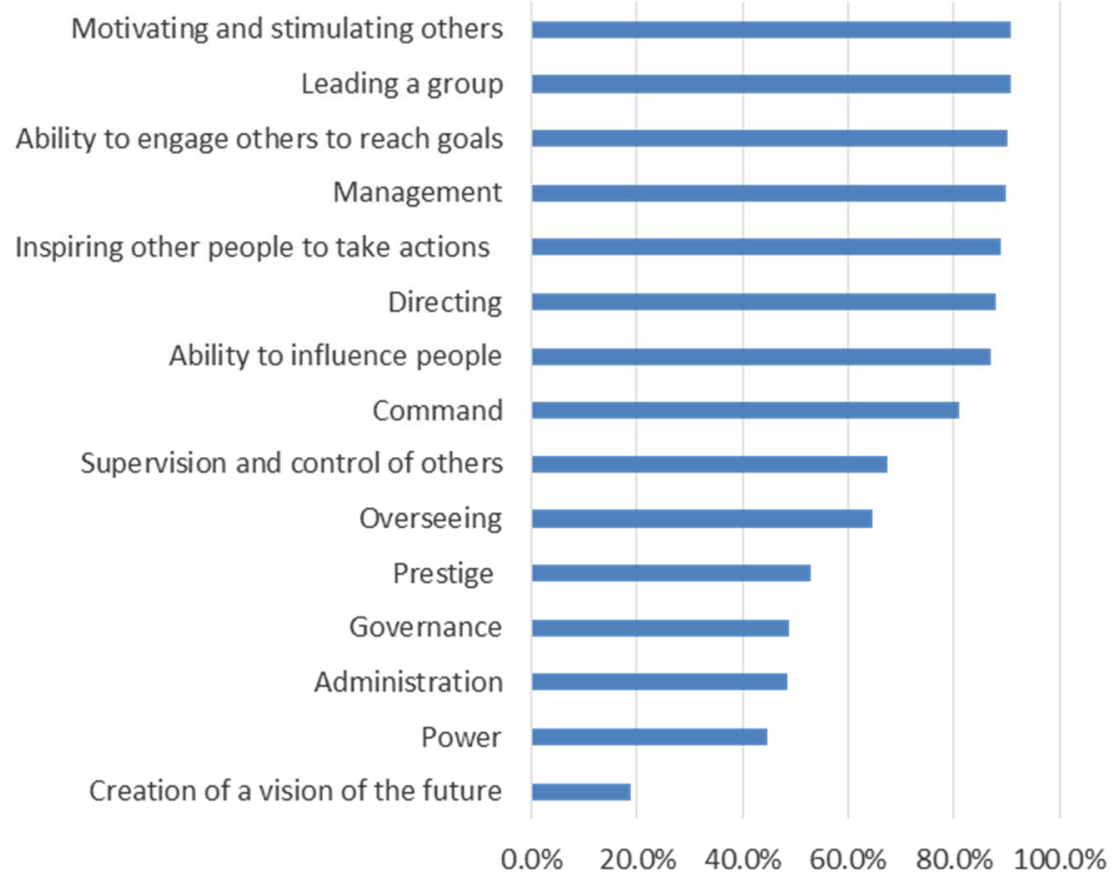

Figure 2. Leadership

Source: Results of a study carried out as part of the "Female Face of Logistics" research programme - May 2019.

According to research participants, leadership definitely means leading a group of people $(90.7 \%)$, motivating and stimulating others to take specific actions $(90.7 \%)$, the 
ability to engage others in the process $(90.0 \%)$, management $(89.8 \%)$, inspiring other people to take actions $(88.7 \%)$, directing $(88.1 \%)$, the ability to influence other people $(87.0 \%)$ and command (81.0\%). Slightly fewer respondents believe that leadership is based on supervision and control of others (67.3\%), overseeing (64.5\%) and prestige (53.0\%). By comparing the variants of the definition of the definition of the term success with the size of the company in which the respondents work, it can be concluded that there is a relationship between the recognition of success understood as conduction (the value $\chi^{2}=5.676$ is statistically significant and the existing relationship is strong $p>0.5$ ), stimulating and stimulating motivation to act (value $\chi^{2}=4.872$ is statistically significant, although the existing relationship is weak $p<0.05$ ), the ability to involve others in the process (value $\chi^{2}=10.335$ is statistically significant, although the existing relationship is weak $p<0.05$ ), management (value $\chi^{2}=5.521$ is statistically significant, although the existing relationship is weak $p$ $<0.05$ ), managing (value $\chi^{2}=5.676$ is statistically significant and the existing relationship is strong $p>0.5$ ), the ability to influence other people (value $\chi^{2}=6,376$ is statistically significant, although the existing relationship is weak $p<0.05$ ) and command (value $\chi^{2}=0.357$ is statistically negligible, but the existing relationship is strong $p>0.5$ ).

Table 1. Qualities, skills and competences that are "definitely" necessary for a leader to lead a group of people $(n=924)$

\begin{tabular}{|c|c|c|c|c|c|}
\hline \multicolumn{2}{|c|}{ Leadership qualities } & \multicolumn{2}{|c|}{ Leadership skills } & \multicolumn{2}{|l|}{ Leadership competences } \\
\hline & \begin{tabular}{|c|} 
Defi- \\
nitely yes
\end{tabular} & & $\begin{array}{c}\text { Definitely } \\
\text { yes }\end{array}$ & & $\begin{array}{c}\text { Definitely } \\
\text { yes }\end{array}$ \\
\hline $\begin{array}{r}\text { Communica- } \\
\text { tiveness } \\
\end{array}$ & $88.3 \%$ & $\begin{array}{r}\text { Communication } \\
\text { skills }\end{array}$ & $82.9 \%$ & $\begin{array}{r}\text { Managing emergency and } \\
\text { conflict situations } \\
\end{array}$ & $71.2 \%$ \\
\hline Authenticity & $73.4 \%$ & Responsibility & $82.5 \%$ & $\begin{array}{r}\text { Ensuring good information } \\
\text { flow within the team }\end{array}$ & $70.1 \%$ \\
\hline Courage & $70.6 \%$ & Creativity & $80.7 \%$ & Constant self-development & $69.9 \%$ \\
\hline Diligence & $67.1 \%$ & Trustworthiness & $75.3 \%$ & $\begin{array}{r}\text { Leading and taking care of the } \\
\text { team }\end{array}$ & $69.7 \%$ \\
\hline $\begin{array}{r}\text { Self-aware- } \\
\text { ness }\end{array}$ & $62.6 \%$ & Self-discipline & $72.1 \%$ & \begin{tabular}{|c|} 
Establishing and keeping good \\
relationships within the team
\end{tabular} & $67.3 \%$ \\
\hline Openness & $62.3 \%$ & Matter-of-factness & $70.1 \%$ & $\begin{array}{l}\text { Supporting other team mem- } \\
\text { bers in their development }\end{array}$ & $65.6 \%$ \\
\hline Frankness & $60.2 \%$ & Innovativeness & $69.7 \%$ & $\begin{array}{r}\text { Having essential knowledge in } \\
\text { a specific field }\end{array}$ & $64.7 \%$ \\
\hline Relationality & $56.1 \%$ & Consistency & $69.7 \%$ & $\begin{array}{c}\text { Supporting employees' initia- } \\
\text { tives concerning innovations }\end{array}$ & $63.4 \%$ \\
\hline Enthusiasm & $55.4 \%$ & Reliability & $68.0 \%$ & $\begin{array}{r}\text { Orientation to reaching long- } \\
\text { term goals }\end{array}$ & $60.6 \%$ \\
\hline Optimism & $50.2 \%$ & Assertiveness & $65.6 \%$ & $\begin{array}{r}\text { Initiating events and pro- } \\
\text { cesses }\end{array}$ & $59.1 \%$ \\
\hline Curiosity & $32.3 \%$ & Business-likeness & $65.2 \%$ & $\begin{array}{r}\text { Orientation to constant } \\
\text { changes }\end{array}$ & $39.8 \%$ \\
\hline- & - & Resoluteness & $63.0 \%$ & Having appropriate education & $25.1 \%$ \\
\hline- & - & Meticulousness & $62.1 \%$ & - & \\
\hline- & - & Self-control & $61.5 \%$ & - & \\
\hline
\end{tabular}

Source: Results of a study carried out as part of the "Female Face of Logistics" research programme - May 2019. 
In addition, identifying the term success with the concept of management (the value $\chi^{2}=2.088$ is statistically significant, although the existing relationship is weak $p<0.05$ ), inspiring other people to act (the value $\chi^{2}=2.244$ is statistically significant, although the existing relationship is weak $p<0.05$ ), prestige (value $\chi^{2}=5,208$ is statistically significant, although the existing relationship is weak $p<0.05$ ) and administration (value $\chi 2=6.428$ is statistically significant, although the existing relationship is weak $\mathrm{p}<0.05$ ).

Most respondents believe that firms need leaders (96.5\%). In their opinion, a leader should possess such qualities as communicativeness $(88.3 \%)$, authenticity $(73.4 \%)$ and courage (70.6\%). In addition, leaders should be characterized by their diligence $(67.1 \%)$, self-awareness (62.6\%), openness (62.3\%), frankness $(60.2 \%)$, relationality $(56.1 \%)$ and enthusiasm (55.4\%). The most desirable skills mentioned by the respondents are communication skills $(82.9 \%)$, responsibility $(82.0 \%)$, creativity $(80.7 \%)$, trustworthiness $(75.3 \%)$, self-discipline (72.1\%) and matter-of-factness (70.1\%). A good leader should also be innovative $(69.7 \%)$, consistent $(69.7 \%)$, reliable $(68.0 \%)$, assertive $(65.6 \%)$, business-like $(65.2 \%)$, resolute (63.0\%), meticulous (62.1\%) and self-controlled (61.5\%). As regards competences, the most desirable include managing emergency and conflict situations (71.2\%), ensuring good information flow within the team $(70.1 \%)$, constant self-development (69.9\%) and leading and taking care of the team (69.7\%).

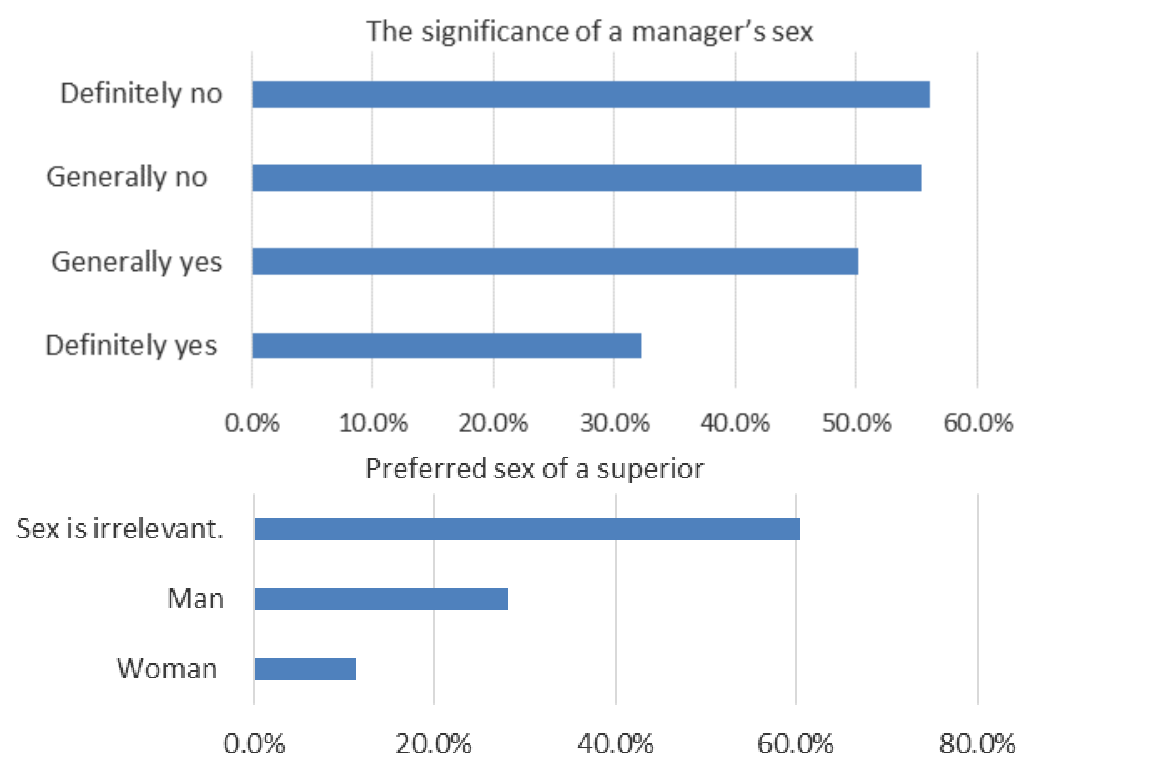

Figure 3. Manager vs. sex - does a manger's sex make a difference? $(n=924)$

Source: Results of a study carried out as part of the "Female Face of Logistics" research programme - May 2019.

In addition, according to the respondents, an effective leader should establish and maintain good relationships within the team (67.3\%), support other team members in their development (65.6\%), have essential knowledge of a specific field (64.7\%), support employees' initiatives concerning innovations (63.4\%) and be oriented towards reaching long-term goals. 
In answer to the question: "Does a manger's sex make a great difference?", most of the respondents answered, "definitely no" (40.69\%) or "generally no" (43.29\%). Only a small group of research participants believes that sex or generally makes a difference $(6.49 \%$ and $9.52 \%$, respectively). This is reflected by the answers to the question: "If you were given a choice, would you prefer your superior to be a woman or a man?". Most of the participants answered that they consider their manager's sex irrelevant $(60.4 \%)$, whereas one in three respondents would prefer a male superior (28.1\%) and only one in ten would rather be subordinate to a woman (11.5\%). This state confirms the existence of a relationship between variables that mean the significance of the manager's supervisor in the context of the size of the company (the value of $\chi^{2}=37.509$ is statistically significant, although the existing relationship is weak $p<0.05$ ), which means that the larger the firm, the more often gender is important, although this is not always important. In contrast, comparing the gender of the superior with the respondent's country, we get a significant interesting relationship (value $\chi^{2}=37.351$, although a weak $p<0.05$ ). So more often in countries such as Great Britain, Germany and Poland superior's gender has more important than in the case of countries such as Spain, Italy, Greece, Croatia and the Czech Republic.

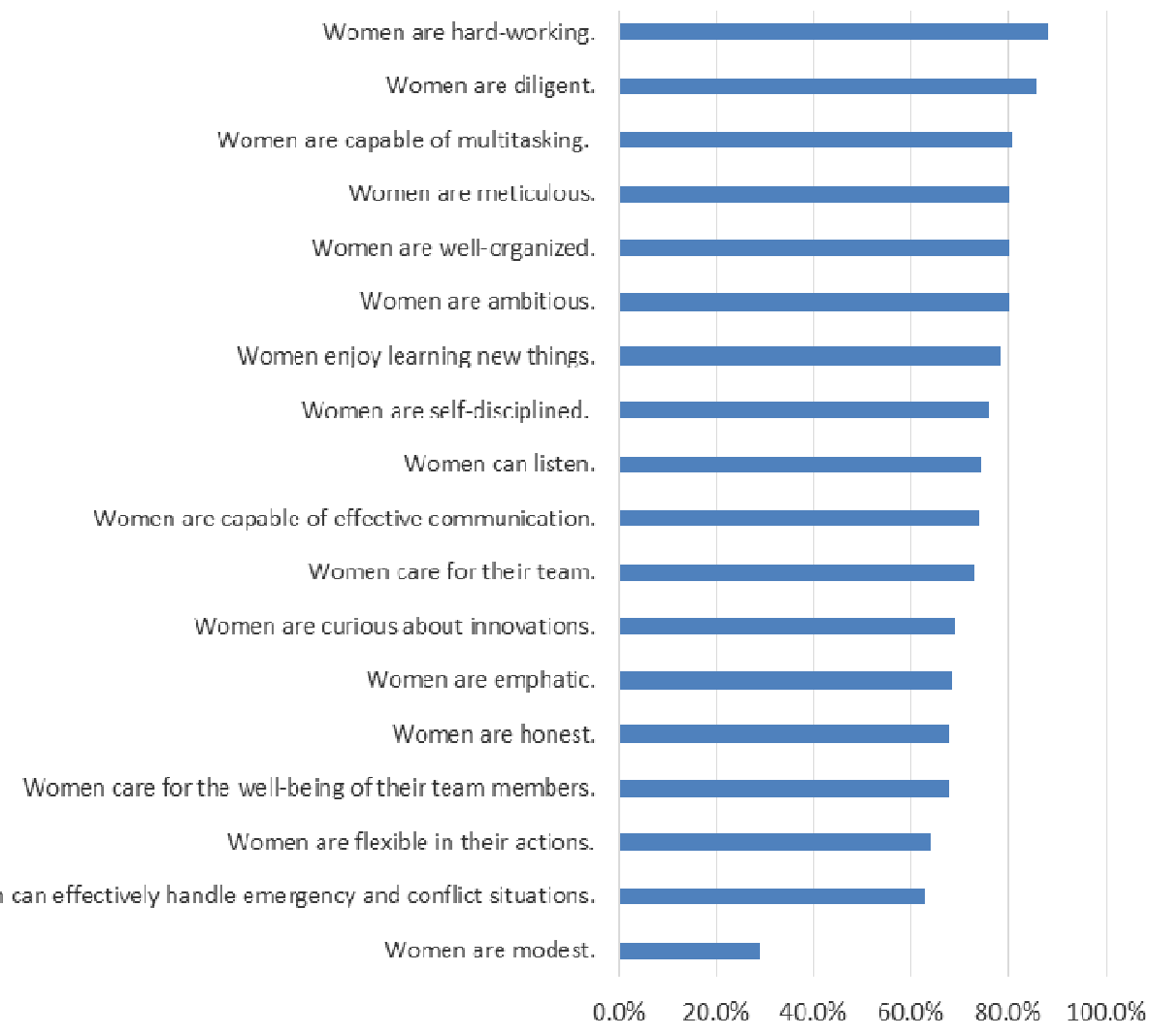

Figure 4. Factors contributing to the effectiveness of female leaders, that influence the results achieved by women-led companies, rated 4 or 5 per $5(n=924)$

Source: Results of a study carried out as part of the "Female Face of Logistics" - May 2019. 
However, women working in logistics, also face many adversities. According to the respondents, these are "definitely" or "generally" the male reluctance to work with women and a fear of strong women (81.0\%), career affecting personal life $(67.1 \%)$, the need to constantly prove something to somebody (66.5\%) and underestimating own successes (61.9\%). Other significant factors include excessive perfectionism (56.3\%) uncertainty and lack of self-esteem (53.0\%).

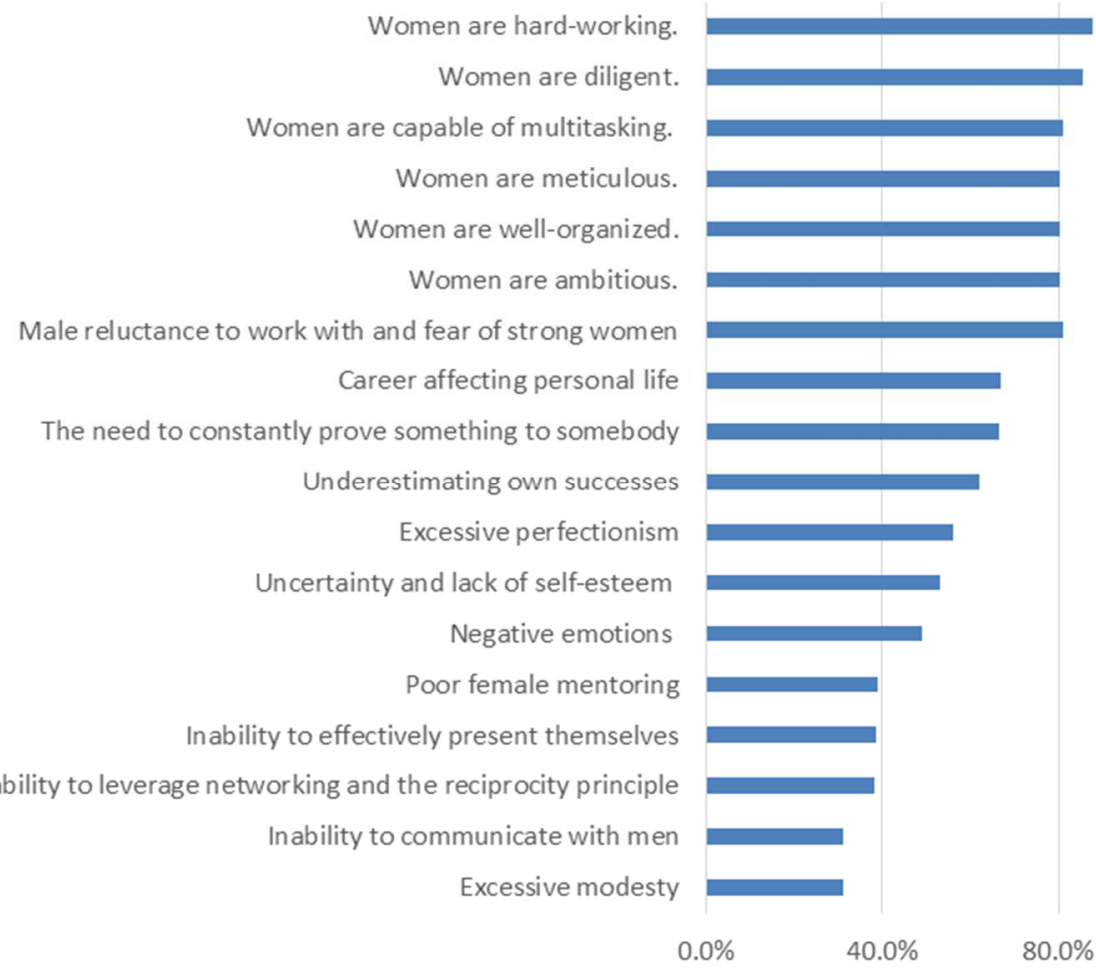

Figure 5. Adversities that women "definitely" or "generally" must face in pursuing their professional career $(n=924)$

Source: Results of a study carried out as part of the "Female Face of Logistics" research programme - May 2019.

According to the respondents, to be successful in business, women working in the logistics industry should clearly and precisely define and express their needs (71.6\%) and have high self-esteem (71.6\%). In addition, women in the logistics industry should make sure that everything they do is charged with positive emotions (56.3\%), improve female mentoring $(45.0 \%)$, celebrate their successes (43.3\%) and know how to leverage networking (43.3\%).

\section{CONCLUSIONS}

Due to their very turbulent environment, organizations must be managed by people who demonstrate appropriate competences. These are not limited to effective administration and task assignment. An important factor contributing to a successful business is also an 
ability to meet the customer's requirements and quickly respond to actions taken by the competition and business partners.

As the conducted research shows, the growing authority of women in the logistics industry results from their having the fundamental qualities and competences that should characterize an effective leader. In addition, some personality traits characteristic of women proves to be extremely useful in the multi-stimuli corporate environment. Therefore, women are perfectly capable of managing logistics.

The logistics industry is transforming in parallel to its environment. Global competition, changing legal regulations and the increasing importance of environmental protection dramatically affect the functioning of logistics companies. However, at the same time, new opportunities are appearing thanks to the implementation of innovative technological solutions. Thus, further development of firms requires human resources that demonstrate appropriate potential, skills and personality traits.

When first introduced, human resource management in firms was considered a necessary evil, however, research reveals a relationship between proper staff management and business success (Sims, 2002). Hence, more often, an equally crucial feature of a leader is the ability to manage people, discover talents and develop them, and - as the research suggests, it is women who most often display it. In addition, women crave success. They often know that, to achieve it, they must perform many functions and prove that they are the best in each of them. When working their way up the ladder, they know that they will not be given a second chance, so they try to accomplish the impossible. This is supposed to ensure their success and open doors to the top of a business hierarchy (Décosterd, 2013).

Research suggests that women are renowned for their ability to "fight for what is theirs," but at the same time, they care for others, which allows them to survive in industries that are largely dependent on relationality and communicativeness, such as the logistics.

\section{REFERENCES}

Belasen, A. (2012). Developing Women Leaders in Corporate America. Santa Barbara: Praeger.

Bonney, G. (2016). In the company of women. New York: Artisan.

David, S. (2016). Emotional agility: get unstuck, embrace change, and thrive in work and life. New York: Penguin Random House.

Décosterd, M.L. (2013). How Women are Transforming Leadership: Four Key Traits Powering Success, Contemporary Psychology. Oxford: Praeger.

Fabińska, M. (2016). Women's road to business success in the era of equal opportunities policy. International Entrepreneurship Review, 2(2), 11-25.

Fitzgerald, T. (2014). Women Leaders in Higher Education. London: Routledge.

Gibb, C. (1970). Leadership. Modern psychology. London: Penguin Books.

Gibson, B., Gibson, M., \& Rutner, S. (1998). Careers in logistics. IL: Council of Logistics Management.

Griffin, R.W. (2016). Management. Boston: South-Western College Publishing.

Ibarra, H., Tannen, D., Williams, J.C., \& Hewlett, S.A. (2018). HBR's 10 Must Reads on Women and Leadership. Boston: Harvard Business Review Press.

Kędziora, D., Piotrowicz, W., \& Kolasińska-Morawska, K. (2018). Employee development and leadership perception in the Polish service delivery centres. Warsaw: Foundation of Management.

Klenke, K. (2004). Women and Leadership A Contextual Perspective. New York: Springer Publishing. 
Kolasińska-Morawska, K. (2014). Success and entrepreneurship in the eyes of Polish emigrants in the British Isles. Journal of Intercultural Management, 6(4).

Lehman, I., Sułkowski, Ł., \& Cap, P. (2019). Leadership, credibility and persuasion. International Review of Pragmatics, 1-17. doi: 10.1163/18773109-01201101.

McClelland, D. (1961). The Achieving Society. New York: Van Nostrand.

Murphy, P., \& Poist, R. (2007). Skills requirements of senior - level logisticians: a longitudinal research assessment. Supply Chain Management: An International Journal, 12(6).

Nkwocha, K. (2013). Success in business. London: CreateSpace.

O'Connor, K. (2010). Gender and Women's Leadership. London: Sage.

Owen, J. (2003). Zarzqqdzanie. Czego nie uczq w szkołach biznesu. Warszawa: PWE.

Rezvani, S. (2009). The Next Generation of Women Leaders. Santa Barbara: Praeger.

Rhode, D.L. (2017). Women and Leadership. Oxford: Oxford University Press.

Robbins, S., \& Judge, T. (2012). Organizational Behaviour. Essex: Pearson Education.

Rossiter, D.E. (2014). Leadership skills. New York: Infobase Publishing.

Sims, R.R. (2002). Organization success through effective human resources management. London: Quorum Books.

Storberg-Walker, J., \& Haber-Curran, P. (2017). Theorizing women \& leadership: new insights \& contributions from multiple perspectives. New York: Information Age Publishing.

Sułkowski, Ł., \& Bogacz-Wojtanowska, E., Wrona, S., Jędrzejczyk-Kozioł, A., Góral, E., Wojdyła, K. (2019). Unsustainable power distribution? Women leaders in polish academia. Economics and Sociology, 12(3), 162-180. doi:10.14254/2071-789X.2019/12-3/11

Unerman, S., \& Jacob, K. (2016). The glass wall: success strategies for women at work - and businesses that mean business. London: Profile Books.

Waters-Sobkowiak, M., Kowalski, T., \& Smits, S. (2018). The Evolving Potential of Talent Management in Poland. Entrepreneurial Business and Economics Review, 6(3), 159-174. https://doi.org/10.15678/EBER.2018.060310 


\section{Authors}

Contribution share of authors is equal and amounted to $33 \%$ each of them.

\section{Katarzyna Kolasińska-Morawska}

Professor at University of Social Sciences (SAN) specializes in issues relaed to modern distribution systems, management of integrated marketing communication processes and modern management concepts in the education and logistics industry.

Correspondence to: Prof. Katarzyna Kolasińska-Morawska, PhD, University of Social Sciences, ul. Sienkiewicza 9, 90-113 Łódź, Poland, e-mail: kkolasinska@san.edu.pl

ORCID (1) http://orcid.org/0000-0002-4035-8272

\section{Łukasz Sułkowski}

Professor of Economics; Associated Professor of humanities in the field of management sciences (Jagiellonian University); Associated Professor of economic sciences in the field of management, economics (University of Economics Oskar Lange in Wrocław, Department of National Economy); Phd in economics in the field of economics and management (University of Economics Oskar Lange in Wrocław, Department of National Economy).

Correspondence to: Prof. Łukasz Sułkowski, PhD, University of Social Sciences, ul. Sienkiewicza 9, 90-113 Łódź, Poland, e-mail: Isukowski@san.edu.pl

ORCID (1) http://orcid.org/0000-0002-1248-2743

\section{Marta Brzozowska}

$\mathrm{PhD}$ in economics in the field of management, logistics (University of Social Sciences, Lodz), Master of Science in Engineering and Manufacturing Management (Coventry University, Coventry, UK), Master of Science in Engineering and Manufacturing Management (Technical University of Lodz, Lodz, PL). Her interests include supply chain management, logistics management, quality management in logistics.

Correspondence to: Marta Brzozowska, PhD, University of Social Sciences, ul. Sienkiewicza 9, 90113 Łódź, Poland, e-mail: mbrzozowska@san.edu.pl

ORCID (10) http://orcid.org/0000-0003-3072-0562

\section{Copyright and License}

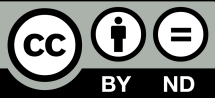

This article is published under the terms of the Creative Commons

Attribution - NoDerivs (CC BY-ND 4.0) License http://creativecommons.org/licenses/by-nd/4.0/

Published by the Centre for Strategic and International Entrepreneurship - Krakow, Poland 
